\title{
E-learning Tools for the Flipped Learning in Elementary School
}

\author{
Kristīne BĀRDULE \\ Liepaja University, Liela street 14, Liepaja, LV-3401, Latvia \\ kbardule@gmail.com
}

\begin{abstract}
Flipped learning is one of the types of blended learning in which technology combines with traditional education. Information and Communication Technologies (ICT) and active learning methods are vital components of flipped learning. Both of them significantly impact the learning environment. In the flipped learning approach, the teacher uses technologies to prepare tasks that students do outside the classroom as homework and organizes an active learning process, provides feedback, and formative assessment during in-class work.

Flipped learning is a widespread approach globally, and there are numerous studies focused on flipped learning in upper-secondary and higher education in different subject areas. Unfortunately, little research supports the incorporation of flipped learning in the elementary classroom and ICT tools appropriate for elementary school students. Therefore, the aim of the study is to analyse conditions that have been considered to select ICT tools for flipped learning, video publishing and collaboration in the lesson, and to evaluate elementary school students' ability to use ICT tools.

There are many practical tools available to enable teachers to create a collaborative environment. Even though the technology is constantly changing, the tools presented here will give teachers an insight into incorporating and using technology when developing students-paced learning process at home and an active, collaborative learning environment in the classroom. In this article's framework the requirement for appropriate flipped learning tools in elementary classes is discussed, and the Case study's data on age-appropriate technologies for primary school students are analysed.
\end{abstract}

Keywords: Flipped Learning, e-Learning, Information and Communication Technologies in Elementary school

\section{Introduction}

Internet and digital devices play a significant role in the school education process. Elearning has become common practice even in primary education. E-learning tools refer to any program, applications, or technology that can be accessed via an internet connection and enhance a teacher's ability to present information and a student's ability to access that information. They provide an opportunity to motivate students, to learn independently, at the appropriate pace and time for everyone, and develop skills needed in real life. 
Today, digital skills are as necessary as literacy and numeracy in terms of their importance, and everyone in all areas of activity needs them. Today's society is closely linked to technological development and digitalization. The use of technology highlights the benefits of broader communication, creative opportunities for expression, learning, and democracy (IAP, 2020). However, the digital learning environment does not always provide effective learning content. The interaction between pedagogical principles and technological possibilities needs to be rethought to create an exciting, motivating learning environment. It is necessary to formulate and show how to realize learning potential by using new pedagogical principles in a technology-rich society. It is clear that technology is no holy grail; instead, technologies used to enable and accelerate specific processes can dramatically improve learning, but its impact depends on its use (Fullan and Langworthy, 2013). As stated in the NESTA report (2013), "The context in which digital technology is deployed needs to change if we are going to drive better educational outcomes".

\section{Technologies for Flipped Learning}

Flipped learning is one of the types of blended learning where the teacher uses technology both for students' work at home to prepare for lessons and in the classroom to organize an active learning process and learn in-depth to provide feedback and formative assessment. Educational technologies and active learning methods are vital components of flipped learning (Bergmann and Sams, 2012).

The implementation of the flipped learning approach requires two main conditions. First, to create and make available for students out-of-class work. The most often used in the flipped learning approach is an instructional video. Second, to plan active teaching methods to learn the topic in more depth that will be used in the classroom (Bergmann and Sams, 2012). In the flipped learning approach, the teacher uses technologies to expand learning opportunities, ensure qualitative communication and interaction, develop students' creative potential, and give appropriate feedback.

\subsection{Video creation steps for out-of-class activities}

To create a video following steps are important - planning, recording, editing, publishing.

Planning. It is necessary to set a goal for the lesson and think about whether this goal better achieves with videos or classroom activities. Language in the video material must be simple, and the concepts explained step by step with additional text, diagrams, and illustrations (Bergmann and Sams, 2012). At the end of the video, it is necessary to summarize and offer two or three short review questions that students must answer to test comprehension (Tomas et al., 2019). When planning a video sequence, it is necessary to rethink the text, select the images to visualize the text; if necessary, provide space for video clips, a digital pen, and a webcam recording. The more complex the video to be prepared, the more attention needs to pay to planning.

Recording. It is possible to use various presentation tools to present the topic on the screen: PowerPoint Prezi, Keynote, Smart notebook, and others (Gonzales, 2019; Yoshida, 2019). Various screen and audio recording programs are available to prepare 
video for out-of-class work, such as Screencast-O-Matic, Screenr, Camtasia Studio (Thomas et al., 2019).

Editing. Editing video is not always necessary. It is possible to correct errors, review the provided information, add the necessary visual materials, highlight, zoom in on the most essential information when editing the material (Bergmann and Sams, 2012).

Publishing. The publication of video material depends on the capabilities of each school, the learning management system (LMS) used, the technological solutions. The most frequently mentioned video publishing sites in the analysed literature are Moodle (Muntean, 2020), Spectrum (Halili et al., 2019), Google Classroom (Abdullah et al., 2019; Jackson, 2019), Edmodo (Yean, 2019), Telegram (Mohammadi et al., 2019), video downloaded on the YouTube channel and embedded in a teacher-created web page (Lee and Lai, 2017; Zamora-Polo et al.,2019).

\subsection{Multimedia resources for out-of-class activities}

In addition to the video, it is useful to add links to tasks for the online comprehension test (Yean, 2019). Thus, the teacher has the opportunity to assess students' understanding of the information provided in the video material, the ability to analyse and evaluate information (Lee and Lai, 2017) examine student progress, proactively respond to students' incomprehensible questions (Zou, 2020).

Some tools provide an opportunity to publish interactive videos. In nearpod.com and edpuzzle.com, the teacher can embed open-ended or multiple-choice questions directly into the video and prepare interactive lessons. Using edpuzzle.com, the teacher has the opportunity to see the student's connection time, the number of views, which issues have caused more difficulty, how many times each fragment has been viewed, the percentage of completion (Abdullah et al., 2019; Jackson, 2019; Zou, 2020). Students can re-watch the video fragments, answer the questions, and immediately receive feedback after submitting the answer (Zou, 2020).

Using nearpod.com, teachers can check students' understanding as they watch the video. When students complete any interactive video activities, that data is available in the post-session reports. The teacher can see a summary of overall participation for each student and detailed responses from students. The teacher can see the student's connection time, the percentage of completion, the number of views, which issues have caused more difficulty. Students can view the video, answer questions, but cannot immediately receive feedback after submitting the answer. The homework assignment should be engaging, containing the most relevant information on the topic to provide feedback from students to the teacher (Woosey and Miles, 2019; Gonzales, 2019; Muntean, 2020).

\subsection{Principles of video creation}

To create a useful video for flipped learning and maximize the benefits of the learning process, the basic principles for its development must be considered. The founders of flipped learning, J. Bergmann and A. Sams (2012), and researchers of flipped learning approach have put forward eleven principles to increase students' perception by watching the video:

1. Keep the video short, up to 10 minutes - 1 minute for students of each grade (Tomas et al., 2019; Yoshida, 2019; Zou, 2020). 
2. Use a joke or an interesting fact at the beginning of the video material to raise interest and motivate students.

3. Include only one topic in the video material, proposing a specific result to be achieved.

4. Change the tone of voice, emphasizing the most significant places when introducing the topic.

5. Create a video like a conversation, thus making the video more impressive and attractive.

6. Use a digital pen to visualize problem-solving steps because the information contained in presentation slides is static, more challenging to understand.

7. Use figures with text that appears and disappears, thus helping students pay attention to keywords, main ideas, and essential facts.

8. Zoom in objects or text discussed at the moment, thus emphasizing the information, action, or tool.

9. Respect copyright.

10. Provide clear, understandable, and straightforward instructions.

11. Set the video material in a user-friendly environment (Lie and Yunus, 2019).

\subsection{Multimedia resources for in-class activities}

In the process of flipped learning, classroom activities are planned in three stages:

1. Testing students' understanding and knowledge of the acquired topic. According to learning purposes, students take a review test usually in digital form (Yoshida, 2019; Muntean, 2020)

2. Organizing dynamic and deep learning process during the lesson. Students create materials that show a deeper understanding of the topic, record videos, podcasts, websites, and blogs, including tutorials and strategies (Lee and Lai, 2017), do laboratory work, cognitive activity, problem-based task, or test (Bergmann and Sams, 2012), do exercises with interactive elements (Tao et al., 2016), participate in competitions, discussions, collaborative activities. Students complete tasks, practice the concepts they have acquired by watching the video (Ansori and Nafi, 2017; Muntean, 2020), perform experiments, prepare presentations, answer the questions (Lee and Lai, 2017; Yean, 2019), ask the questions themselves, seeking for answers to them (Muntean, 2020). Thus, learning becomes interactive and effective (Gonzales, 2019),

3. Review students' created works at the end of the lesson. Discussions of the work done (Tomas et al., 2019), game-based activities could be implemented according to the content to be learned - quizzes in the Kahoot, Socrative, Quizziz, Padlet (Zamora-Polo et al., 2019).

\section{Evaluation of e-learning tools}

To use educational technologies for learning in elementary education it is vitally important to evaluate these tools and choose the best solutions for young learners. Analysing the information above about the basic principles for creating video material and scientific literature on age-appropriate e-learning tools, a list of conditions that a teacher must follow in selecting e-learning tools has been created. 
Teacher must consider e-learning objectives to prepare course content. It should be built on a foundation of clear learning objectives, aligned to state standards. Courses should be competency-based and should frequently assess student progress. Tools need to engage learning at a deeper level (Grimm, 2018). Tools should abide by the Children's Online Privacy Protection Act. Tools must not contain any indication of violence or stereotyping (Papadakis and Kalogiannakis, 2017).

From the student's perspective, there are four principles significant:

\section{Technical function}

1. The availability of material to the student is essential. Necessary to think about ways to reduce the effort required to act by minimizing the number of clicks from logging in to starting their work (NESTA, 2020).

2. The tool must be intuitive to complete tasks (Papadakis and Kalogiannakis, 2017).

Visual impact

1. The visual design of the material should be appropriate for the age of the students. The younger students, the shorter, more colourful, and more illustrated the video material or activity should be (Yean, 2019).

2. Textual information should be presented in an easy-to-understand and memorable way, based on research into easier-to-understand font style, size, line spacing, text placement, font, and background colour. These recommendations are significant to maximize the perception of information through visual processes, thus helping the learning process and facilitating memorization (Mackare et al., 2018).

\section{Language}

1. It is essential that guidelines are clear and instructions are as simple and straightforward as possible. It is recommended to present the most important information early, ideally, in the first sentence (NESTA, 2020).

2. Language must be simple and easily understandable for elementary students (NESTA, 2020, Yean, 2019).

\section{Engagement}

1. Students must enjoy learning in the virtual environment. Tools should engage students by providing them with a choice of when and how they learn (Bergmann and Sams, 2015).

2. Student must get timely, complete, and proper feedback on assignments and activities (Abou-Khalil et al., 2021; Mousavia et al., 2020).

3. Tools should offer opportunities for creativity and interaction, not just passive learning (Mousavia et al., 2020). Student engagement is fostered when students can collaborate with other students during the learning process.

4. Tools designed to deliver content should pre-assess student knowledge and use that knowledge to construct learning activities at the student's zone of proximal development. When students have choice and content is at the correct level of difficulty, learning is more enjoyable and more engaging (Grimm, 2018).

Common praxis is to use video for out-of-class activities and digital tools for content creation, feedback, assessment, cooperation for in-class activities when apply flipped learning approach. In scientific literature there are mentioned use of Google Classroom (Jackson, 2019), Seesaw (Woosey and Miles, 2019), Edmodo (Yean, 2019) as learning management systems for publishing out-of-class videos and information for students, evaluation and collaboration. There are mentioned Edpuzzle (Jackson, 2019; Zou, 2020), Nearpod, Kahoot, Socrative, Quizziz, Padlet (Zou, 2020) as tools for out-of-class and inclass activities for elementary school students. 
Table 1. Criteria to evaluate e-learning tools

\begin{tabular}{|c|c|c|c|c|}
\hline General & $\begin{array}{c}\text { Technical } \\
\text { functions }\end{array}$ & Visual impact & Language & Engagement \\
\hline content & easy to login & text & $\begin{array}{c}\text { clear } \\
\text { instructions }\end{array}$ & self-paced \\
\hline security & intuitive & pictures & $\begin{array}{c}\text { simple } \\
\text { language }\end{array}$ & feedback \\
\hline
\end{tabular}

For publishing out-of-class information the teachers in elementary school in Liepaja use LMS Microsoft365 and student management system e-class. For out-of-class and inclass activities the teachers of Liepaja school used tools are similar to those which use the teachers in the world. For out-of-class and in-class activities teachers use Edpuzzle, Nearpod, Kahoot, Socrative, Quizziz, Padlet, Liveworksheets and tools developed for Latvian education system - Uzdevumi, Soma. The teachers use ICT tools according to their choice which they are familiar with and which are easy to use for students. They used these ICT tools in face-to-face learning but during remote learning in Covid19 pandemic time the use of the digital e-learning tools increase.

In Table 2 are compared the tools (basic plans - free version) used in elementary school in Liepaja.

Table 2. Comparison of digital tools according to criteria

\begin{tabular}{|l|l|l|l|l|}
\hline Tool & $\begin{array}{l}\text { Technical } \\
\text { function }\end{array}$ & Visual impact & Language & Engagement \\
\hline Uzdevumi.lv & $\begin{array}{l}\text { e-class log-in } \\
\text { and password }\end{array}$ & $\begin{array}{l}\text { Video \& } \\
\text { images, no } \\
\text { possibility to } \\
\text { make changes } \\
\text { in text style }\end{array}$ & $\begin{array}{l}\text { Ready \& } \\
\text { teachers } \\
\text { created } \\
\text { information }\end{array}$ & $\begin{array}{l}\text { Visual } \\
\text { (images), } \\
\text { textual } \\
\text { information, } \\
\text { test, automatic } \\
\text { feedback, self- } \\
\text { paced }\end{array}$ \\
& $\begin{array}{l}\text { e-class log-in } \\
\text { and password }\end{array}$ & $\begin{array}{l}\text { No possibility } \\
\text { to make } \\
\text { changes }\end{array}$ & $\begin{array}{l}\text { Ready } \\
\text { information }\end{array}$ & $\begin{array}{l}\text { Visual (video, } \\
\text { images), } \\
\text { textual } \\
\text { information } \\
\text { and/or test, } \\
\text { automatic } \\
\text { feedback, self- } \\
\text { paced }\end{array}$ \\
& & & & \\
\end{tabular}




\begin{tabular}{|c|c|c|c|c|}
\hline Liveworksheets & $\begin{array}{l}\text { Own created } \\
\text { log-in name } \\
\text { and password }\end{array}$ & $\begin{array}{l}\text { Video \& } \\
\text { images, minor } \\
\text { possibilities to } \\
\text { make changes } \\
\text { in text style }\end{array}$ & $\begin{array}{l}\text { Teachers } \\
\text { created } \\
\text { information }\end{array}$ & $\begin{array}{l}\text { Test, } \\
\text { automatic } \\
\text { feedback, self- } \\
\text { paced }\end{array}$ \\
\hline Quizziz & Class code & $\begin{array}{l}\text { Images, no } \\
\text { possibility to } \\
\text { make changes } \\
\text { in text style }\end{array}$ & $\begin{array}{l}\text { Teachers } \\
\text { created } \\
\text { information }\end{array}$ & $\begin{array}{l}\text { Interactive } \\
\text { lesson and/or } \\
\text { quiz, } \\
\text { automatic } \\
\text { feedback, self- } \\
\text { paced }\end{array}$ \\
\hline Nearpod & Class code & $\begin{array}{l}\text { Video \& } \\
\text { images, minor } \\
\text { possibilities to } \\
\text { make changes } \\
\text { in text style }\end{array}$ & $\begin{array}{l}\text { Teachers } \\
\text { created } \\
\text { information }\end{array}$ & $\begin{array}{l}\text { Interactive } \\
\text { lesson and/or } \\
\text { quiz, } \\
\text { automatic } \\
\text { feedback }\end{array}$ \\
\hline Edpuzzle & $\begin{array}{l}\text { sign up for the } \\
\text { first time after } \\
\text { use class code }\end{array}$ & $\begin{array}{l}\text { Video, no } \\
\text { possibility to } \\
\text { make changes } \\
\text { in text style }\end{array}$ & $\begin{array}{l}\text { Teachers } \\
\text { created } \\
\text { information }\end{array}$ & $\begin{array}{l}\text { Interactive } \\
\text { video, } \\
\text { automatic } \\
\text { feedback, self- } \\
\text { paced }\end{array}$ \\
\hline Padlet & link & $\begin{array}{l}\text { Video, images } \\
\& \text { documents } \\
\text { no possibility } \\
\text { to make } \\
\text { changes in text } \\
\text { style }\end{array}$ & $\begin{array}{l}\text { Teachers } \\
\text { created } \\
\text { information }\end{array}$ & $\begin{array}{l}\text { Students can } \\
\text { interact with } \\
\text { each other, } \\
\text { students' \& } \\
\text { teacher's } \\
\text { feedback }\end{array}$ \\
\hline Google Forms & link & $\begin{array}{l}\text { Video, images } \\
\& \text { documents } \\
\text { no possibility } \\
\text { to make } \\
\text { changes in text } \\
\text { style }\end{array}$ & $\begin{array}{l}\text { Teachers } \\
\text { created } \\
\text { information }\end{array}$ & $\begin{array}{l}\text { Interactive } \\
\text { lesson and/or } \\
\text { quiz, } \\
\text { automatic } \\
\text { feedback, self- } \\
\text { paced }\end{array}$ \\
\hline Socrative & Class code & $\begin{array}{l}\text { Images, no } \\
\text { possibility to } \\
\text { make changes } \\
\text { in text style }\end{array}$ & $\begin{array}{l}\text { Teachers } \\
\text { created } \\
\text { information }\end{array}$ & $\begin{array}{l}\text { Test, } \\
\text { automatic } \\
\text { feedback, self- } \\
\text { paced }\end{array}$ \\
\hline Kahoot & Class code & $\begin{array}{l}\text { Images \& } \\
\text { video, no } \\
\text { possibility to } \\
\text { make changes } \\
\text { in text style }\end{array}$ & $\begin{array}{l}\text { Teachers } \\
\text { created } \\
\text { information }\end{array}$ & $\begin{array}{l}\text { Test, } \\
\text { automatic } \\
\text { feedback, self- } \\
\text { paced }\end{array}$ \\
\hline
\end{tabular}

\section{Methodology}

Case study was conducted in one Liepaja elementary school to analyse students' ability, skills, and engagement using digital tools in the e-learning process. Ninety-eight students 
from grades 5 and 6 (11-12 years old) participate in qualitative research. All involved students use these tools in ordinary lessons, and fifty-two 6th grade students use these tools in flipped lessons. Students of grades 5 and 6 were chosen because according to Piaget children are in the formal operational stage of cognitive development, beginning at the age of 11-12. At this point in development, children can think about abstract and theoretical concepts and use logic to come up with creative solutions to problems and evaluate their actions and feelings (Dean, 2021).

Participants of the study were requested to assess the used e-learning tools, marking the appropriate criteria for each tool. In the questionnaire there was given 3 criteria technical functions, visual impact, instructional clarity. Respondents had the opportunity to mark more than one criterion for each tool. Participants were requested to evaluate 5 statements related to the engagement. They marked one most appropriate answer to each statement: "Totally agree," "Agree," "Disagree," "Totally disagree."

Statements were chosen based on analysed scientific literature about conditions that have been considered to select appropriate e-learning tool for elementary students.

Despite the fact that the visual image of each ICT tool used was included in questionnaire it was difficult for elementary school students to accurately remember, describe and explain their feelings or learning processes to evaluate various e-learning tools. According to Covid19 pandemic and remote learning the students cannot get support from the teacher or researcher during responding to the questionnaire.

The obtained data cannot be generalized, because the students evaluated only 8 statements, which is not enough to assess the reliability. However, the results indicate trends in information perception and engagement using these ICT tools.

\section{Results}

In order to find out the opinion of students about the technical functions and instructional design of e-learning tools, students assessed the used e-learning tools, marking the appropriate criteria for each tool: "It is easy to understand how to use it," "The information is understandable," "Instructions are simple."

Students have access to uzdevumi.lv and soma.lv using e-class log-in name and password, to liveworksheets.com using their own created log-in name and password, to padlet.com and google forms using teacher's created link, to quizizz.com, nearpod.com, socrative.com, kahoot.it using the teacher's created class code to edpuzzle.com sign up for the first time after they use the teacher's created class code.

Figure 1 shows students' assessment results of e-learning tools. $60 \%$ and above the students consider that it is easy to understand how to use socrative.com $(100 \%)$, liveworksheets.com (65\%), uzdevumi.lv (62\%), quizziz.com, kahoot.it (61\%), padlet.com, Google Forms $(60 \%)$. It is easy to login and they are intuitive. Technical functionality of edpuzzle.com (56\%), soma.lv (52\%) and nearpod.com (46\%) students evaluate lower.

$50 \%$ and above of students consider that the information is visually perceptible in edpuzzle.com (50\%), socrative.com (55\%), google forms (57\%). Visual perception of other e-learning tools is evaluated lower.

$54 \%$ of students agree that language is simple and instructions are clear in soma.lv. Criteria "Language" in other e-learning tools is evaluated lower from $18 \%$ till $44 \%$. $18 \%$ of students agree that instructions are clear and language is simple in liveworksheets.com and socrative.com. The highest rate in criteria "Language" was 
evaluated e-learning tool edpuzzle.com. $44 \%$ of students agree that instructions are clear and language is simple in edpuzzle.com.

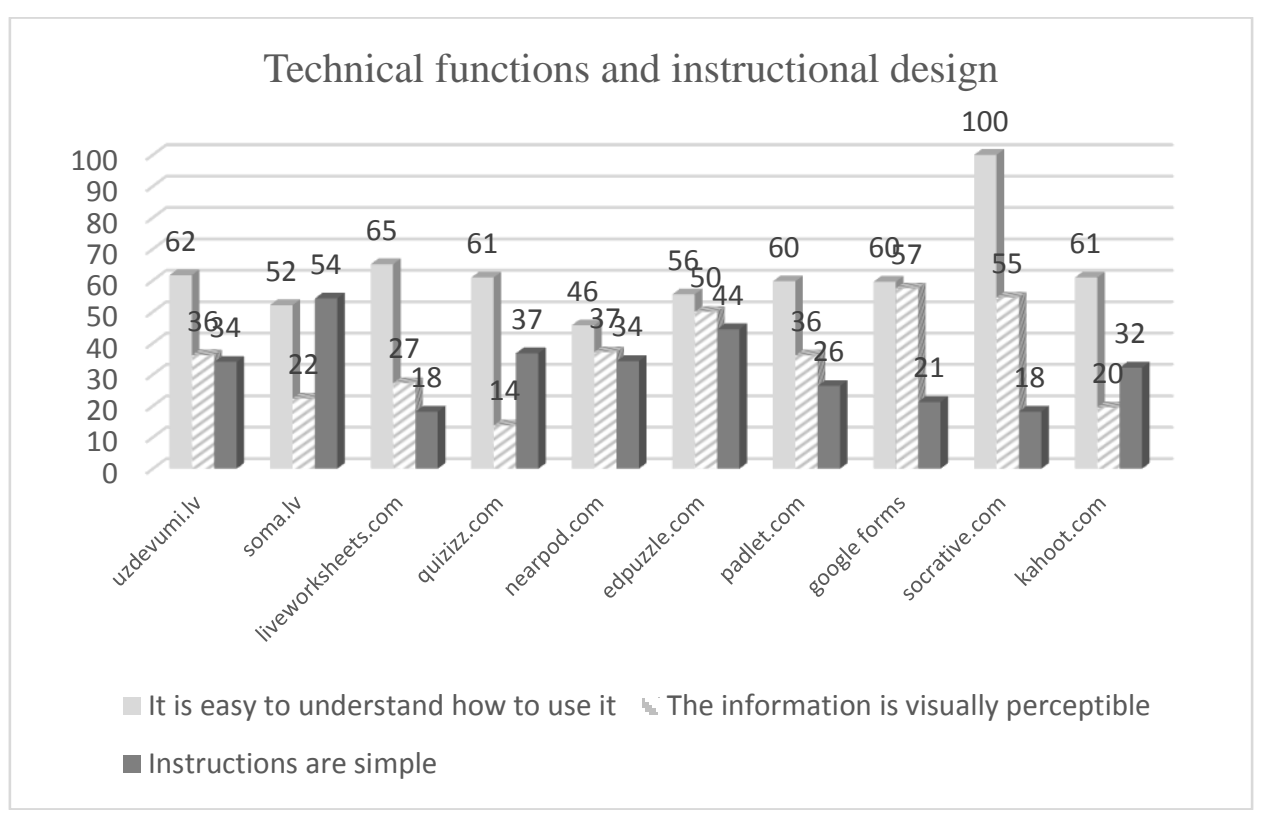

Figure 1. Evaluating of e-learning tools

In order to find out the opinion of students' engagement when using e-learning tools, students assessed the agreement to the given statements: "I like to learn in time and peace appropriate for me," "I like that I get immediate feedback," "I like that I can correct the result if it doesn't satisfy me," "I like to work in groups," "Tasks are at the appropriate level of difficulty."

Figure 2 shows students assessment results of engagement with e-learning tools. $94 \%$ of students (agree $51 \%$, totally agree $43 \%$ ) like to choose when to study; they like to study in their own pace. $95 \%$ of students (agree 33\%, totally agree 62\%) like to check their answers themselves and get immediate feedback in the tool. 99\% of students (agree $29 \%$, totally agree $70 \%$ ) appreciate that they can correct their work if the result is not satisfactory, so they have the opportunity to learn more, remember better, improve their skills and knowledge.

Results show shared opinions about collaboration using e-learning tools and appropriateness of learning activities at the student's zone of proximal development. $57 \%$ of students like to collaborate with classmates using e-learning tools (agree $41 \%$, totally agree $16 \%$ ), but almost half do not like collaborative activities using e-learning tools during the learning process. $64 \%$ of students (agree $44 \%$, totally agree $20 \%$ ) agree that content is in an appropriate level of difficulty. 


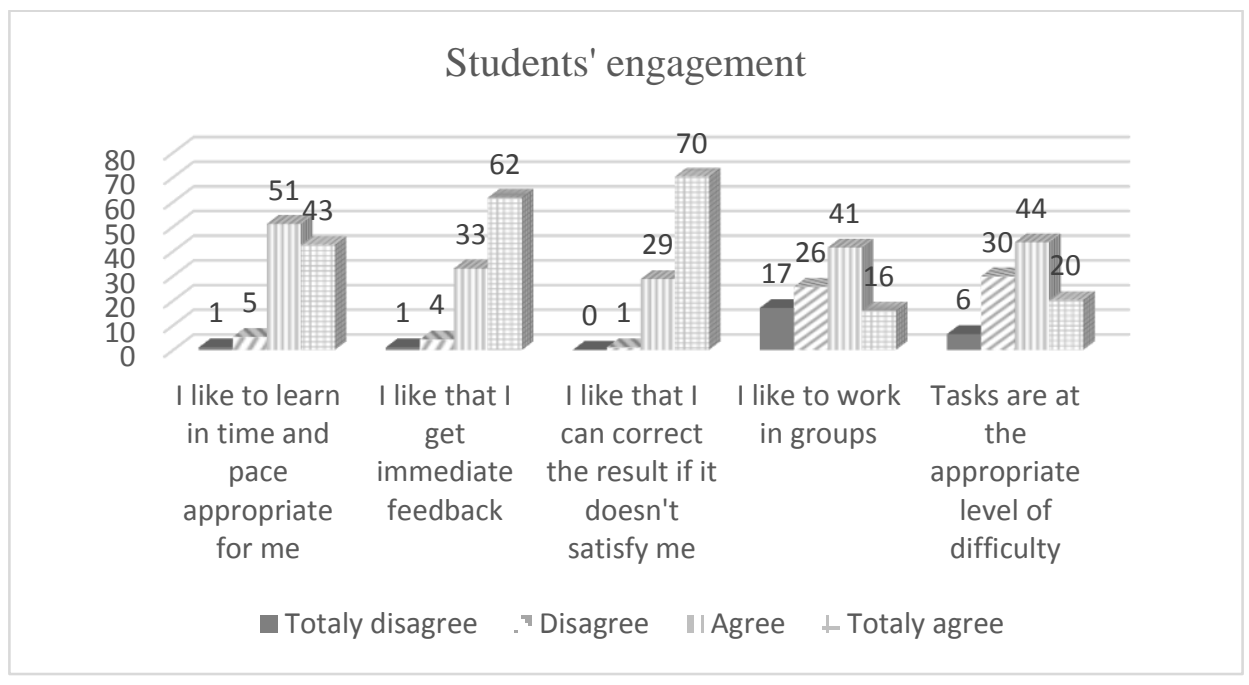

Figure 2. Evaluating of engagement with e-learning tools

\section{Discussion}

In criteria "Technical function" students rated higher e-learning tools socrative.com, liveworksheets.com and uzdevumi.lv. According to Papadakis and Kalogiannakis (2017) the tool must be intuitive. Socrative.com, liveworksheets are very intuitive to complete tasks. Students need time to get to know and use digital e-learning tools effectively. The learning time for each student may vary depending on perception (Zou, 2020; Grimm, 2018). Students use uzdevumi.lv for a long time, and it is well known for them, so they evaluate its technical functionality high. Students use e-learning tools nearpod.com and edpuzzle.com rarely and soma.lv only recently, so they are not accustomed to them and evaluate their technical functionality lower.

Teachers cannot affect criteria "Visual impact" because each platform has its design, build-in interface. The teacher can add images and/or videos appropriate to the topic, in some tools there is the possibility to change the font, but these options are not many and do not meet K. Mackare's (2018) recommendations about the perception of information through visual processes.

Students rated soma.lv the highest in the "Language" criterion. In the e-learning environment soma.lv, the offer of learning content is constantly expanding. Experts in the field of education create the content of studies and the instructions of tasks. That is one reason to explain why the language of information and instructions of the tasks offered by soma.lv are easy to understand and appropriate to the age of the students (Grimm, 2018). In other e-learning tools, teachers write instructions themselves, so they have to consider writing instructions easily and comprehensively (NESTA, 2020; Yean, 2019). 
The results revealed that most students like the opportunity to learn in their own time and pace, get immediate feedback, and repeat tasks if the results do not satisfy them. (Bergmann and Sams, 2015; Abou-Khalil et al., 2021; Mousavia et al., 2020).

However, the results also indicated that students have a different opinion about collaborative activities and the appropriateness of course content, which points to a lack of the necessary collaboration skills and different levels of cognition (Grimm, 2018). Students differ according to their social skills, perception, learning skills, cognitive development. It could be explained with the psychology of the primary school students, lack of skills or personality character traits (NESTA, 2020). In every class, some students need scaffolding to understand topics concepts - teacher's support, additional prompts, individual clarification. Teachers have to differentiate content, process and product according to the students' individual needs, psychological characteristics and cognitive abilities to reach every student in every class (Bergmann and Sams, 2015).

\section{Conclusions}

This study explored primary school students' perception and experience of using elearning tools in an ordinary and flipped classroom.

- The findings of this study give insight to teachers regarding integrating various media resources for better education in elementary school to make learning active, accessible, and accountable using technology.

- Using presented principles and tools, teachers can choose the most appropriate e-learning tools, arrange instructions and prepare content based on their students' perception to enhance learning outcomes.

- Teachers have both the challenge and the responsibility to ensure that students' interactions with technology are developmentally relevant, interactive, and beneficial to cognitively active, deeply engaging, meaningful, and socially interactive learning.

However, there are some limitations of this study that need to be addressed in future research.

- First of all, it is difficult for elementary school students to accurately remember, describe or explain their feelings or learning processes to evaluate various elearning tools. In order to get a more objective opinion, it would be necessary to find out the students' opinion about functionality of the ICT tool immediately after its use. Thus, other data collection methods would need to be used to obtain additional valuable information on elementary school students' perceptions of e-learning in future research.

- Secondly, it would be necessary to explore the use of on-screen text formatting parameters, which should be used to maximize the perception of information by elementary school students through visual processes, thus helping the learning process and facilitating memorization.

- Thirdly, it is necessary to analyse the abilities of the youngest primary school students $(7-9$ years old) to use e-learning tools in the learning process, the conditions that encourage them to perform tasks, engage in activities. 


\section{Acknowledgement}

The publication is made with the financial support of the project No. 8.2.2.0/18/I/003 "Improvement of the academic staff of the University of Liepaja in the fields of strategic specialization - speech therapy, pre-school education and primary education" and of the project No. 1.1.1.5/18/I/018 "Promotion of research, innovation and international cooperation in science at Liepaja University".

\section{References}

Abdullah, M.Y., Hussin, S., Ismail, K. (2019). Implementation of Flipped Classroom Model and Its Effectiveness on English Speaking Performance. iJET, 14, 130-147.

Abou-Khalil, V., Helou, S., Khalifé, E., Chen, M.A., Majumdar, R., Ogata, H. (2021) Emergency Online Learning in Low-Resource Settings: Effective Student Engagement Strategies. Educ. Sci. 2021, 11, 2-18.

Ansori, M., Nafi, N.N. (2018). English teachers perceived benefits and challenges of flipped classroom implementation. JEELS, 5, 211-227.

Bergmann, J., Sams, A. (2012). Flip Your Classroom Reach Every Student in Every Class Every Day, International Society for Technology in Education, Washington, DC.

Bergmann, J., Sams, A. (2015). Flipped learning for Elementary Instruction, International Society for Technology in Education, Washington, DC.

Binit Halili, S.H., Hijja, N., Rabihah, N., Sulaiman, H., Razaket, R.A. (2019). Exploring the flipped classroom approach in the teaching and learning process: a case study of preservice teachers' views. Int. J. of Pedagogies \& Learning. 14, 1-17.

Dean, J. (2021). McDonald and Avery's Dentistry for the Child and Adolescent, 11 edn, Elsevier, Health Sciences.

Fullan, M., Langworthy, M. (2013). Towards a New End: New Pedagogies for Deep Learning, available at http://www.newpedagogies.nl/images/towards_a_new_end.pdf

Gonzales, R.R. (2019). Flipped Classroom Approach: Experiences from a Philippine State University, The Normal Lights, Journal of Teacher Education. 13, 67-89.

Grimm, P. (2018). How to Evaluate EdTech Tools that Support Teaching \& Learning, available at https://blog.edmentum.com/how-evaluate-edtech-tools-support-teaching-learning

IAP (2021). Guidelines for the development of education for 2021-2027. "Future skills for the society of the future" (Latvian), Ministry of Education and Science of Latvia, Riga

Jackson, N. (2019). Benefificial or Not: Flipped Learning in an Elementary Mathematics Classroom. Capstone Projects and Master's Theses. California State University, Monterey Bay, USA

Lee, K., Lai, Y. (2017). Facilitating higher-order thinking with the flipped classroom model: a student teacher's experience in a Hong Kong secondary school. RPTEL, 12, 1-14.

Lie, W.W., Yunus, M.M. (2019). Flipped for a Betterment: The Acceptance Level Towards Flipped Learning Among Malaysian ESL Learners, JED, 3, 69-75.

Mackare, K., Jansone, A., Medveckis, A. (eds) (2018). Recommendation guidelines for designing $e$-study materials, Society and Culture. Collection of articles, XX, LiePA, Liepaja

Mohammadi, J., Barati, H., Youhanaee, M. (2019). The Effectiveness of Using Flipped Classroom Model on Iranian EFL Learners' English Achievements and Their Willingness to Communicate, ELT CCSE. 12, 101-115.

Mousavia, A., Mohammadia, A., Mojtahedzadeha, R., Shirazib, M., Rashidi, H. (2020). E-learning educational atmosphere measure (EEAM): a new instrument for assessing e-students' perception of educational environment, $R L T$. 28, 1-12. 
Muntean, C.H., Graziano, K. (ed.) (2019) Teaching Tip: Flipping the Class to Engage Students in Learning Programming Algorithms, Proc. SITE International Conference (18 Mar, 2019, Las Vegas, NV, United States), AACE, Waynesville, NC USA.

NESTA (2013). Bringing great ideas to life, available at https://media.nesta.org.uk/documents/nes001_annualreview_v37.pdf

NESTA (2020). Applying Behavioural Insights in EdTech, available at https://www.nesta.org.uk/report/behavioural-insights-edtech/

Papadakis, S., Kalogiannakis, M. (2017). Mobile educational applications for children: what educators and parents need to know, IJMLO. 11, 256-277.

Tao, S.Y., Huang, Y.H., Tsai, M.J. (2016). Applying the Flipped Classroom with Game-Based Learning in Elementary School Students' English Learning, Proc. $5^{\text {th }}$ International EITT Conf., (22-24 Sept. 2016, Tainan, Taiwan), IEEE, Los Alamitos, CA.

Tomas, L., Evans, N., Doyle, T., Skamp, K. (2019). Are first year students ready for a flipped classroom? A case for a flipped learning continuum, IJET in Higher Education. 16, 122.

Woosey, J., Miles, L. (2019). Flipped Learning. International Journal of Teacher Leadership, 10, 116-127.

Yean, L.S. (2019). Promoting active learning and independent learning among primary school students using flipped classroom, IJEPC. 4, 324-341.

Yoshida, H., Gómez C. I. (eds) (2019). Flipped learning for pre-service teacher education: with focus in instructional design for elementary and secondary education, Proc. 13th INTED2019 Conf. (11th-13th March 2019, Valencia, Spain), IATED Academy, Valencia.

Zamora-Polo, F., Corrales-Serrano, P.M., Sánchez-Martín, J., Espejo-Antúnez, L. (2019). Nonscientific University Students Training in General Science Using an ActiveLearning Merged Pedagogy: Gamification in a Flipped Classroom, MDPI Education Science. 9, 2-18.

Zou, D (2020). Gamified flipped EFL classroom for primary education: student and teacher perceptions, JCE. 7, 213-228.

\section{Author's information}

Kristīne Bārdule, Mg. paed. Head teacher at Liepaja Centre Primary School and teacher of history. In collaboration with the Ministry of Education carried out content analysis of compulsory education. Graduated in the Pedagogical Masters programme at the University of Liepaja in 2011. Currently a PhD student at the Faculty of Natural and Social Sciences, at the University of Liepaja in the study programme "E-studies Technologies and Management". Main research interests: using information and communication technologies as tools in educational process, especially in elementary school.

Received May 30, 2021, revised November 30, 2021, accepted December 11, 2021 